\title{
US boosts military support of campus research
}

\section{Defense Department support for basic science is returning} to pre-Mansfield Amendment days. David Dickson reports

AFter a gap of seven years, the US Department of Defense has reestablished an office to co-ordinate its efforts in basic research and to stimulate contacts with university research groups.

This move, which was recommended in a report on the department's basic research released by the Office of Science and Technology Policy in Washington last week, reflects an effort backed by President Carter to restore military support for university research to the levels of the late 1960s. Two factors have brought this about: renewed pressure for technological innovation-with requirements ranging from laser weapons to high-speed integrated circuits-within the Department of Defense; and the continued squeeze on other sources of support for university research.

The clearest evidence of the new trend is provided in the budget request submitted by the President to Congress last month. This asked for $\$ 436$ million for basic research obligations in the Department of Defense in the fiscal year 1980 , almost $10 \%$ of the total basic research budget. If the request is accepted by Congress, this would mean an average increase for Defense Department basic research in the two Carter budgets (covering the period $1978-80$ ) of $18.3 \%$. considerably higher than for any other agency. and compared to an average increase of $11.4 \%$ for the National Institutes of Health, and $10.5 \%$ for the National Science Foundation.

Military support for basic research reached its peak in the late 1960s, when the efforts of university scientists in fields such as nuclear weapons were

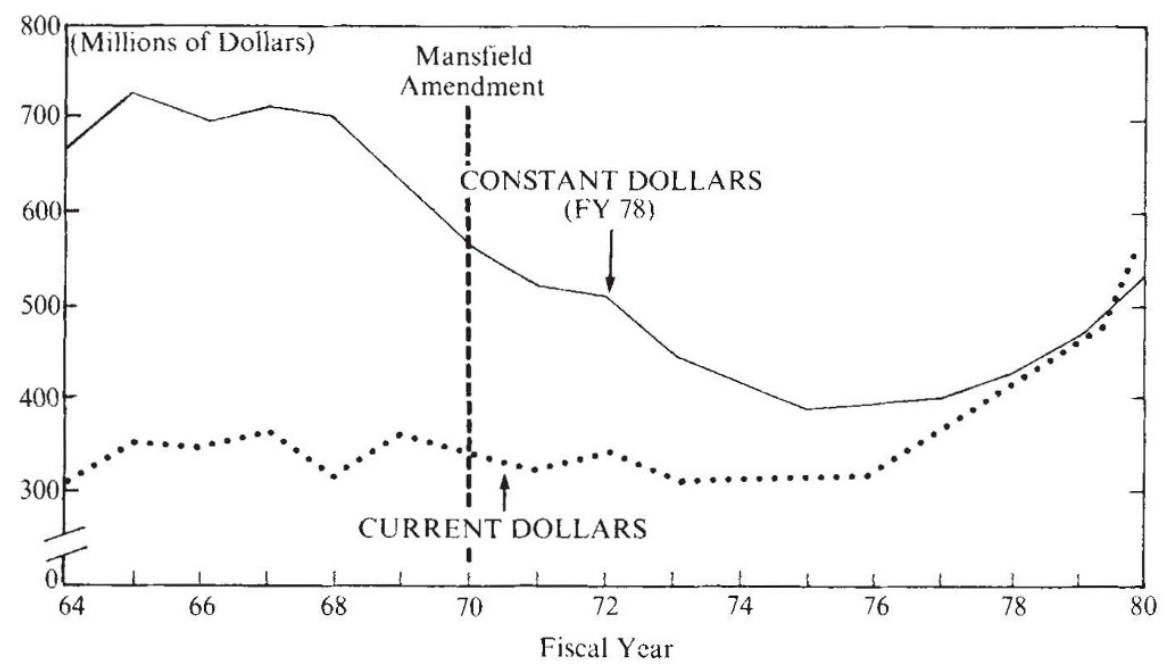

Basic research spending by the Department of Defense. 1954 1989. (Source DolD/OSTP) supplemented by those recruited to support US efforts in Vietnam. Reaction against the conduct of the war, however, and the use of science in areas such as chemical weapons or counter-insurgency techniques, led to a wave of protests about military involvement on university campuses.

The protests became focused in an amendment made by Senator Mansfield to the Defense Department appropriations in 1970. Seen by some as merely a "good housekeeping" move, hut by others as reflecting broader concerns about military involvement with science, the amendment stated that funds would only be provided to research projects bearing a "direct and apparent relationship" to a specific military function or operation.

Although revised a year later to require merely a "potential relationship" -a criterion which is still in effect-the Mansfield amendment contributed to a rapid shrinkage in Defense Department support for basic science, which in real terms was almost halved between 1967 and 1975.

In its report, the OSTP panel, which was chaired by Dr J. K. Galt of Sandia Laboratories and included representatives of universities. industry and other government agencies. states its belief that the current level of funding has reduced the utilisation of basic research in the Department of Defense "below a minimally acceptable level". It "welcomes and applauds" recent attempts to reverse the previous decline in research funding.

The panel says that such research is important to the department for three main reasons: to fill gaps in knowledge. to provide a source of new concepts. and to keep up with technological developments in other parts of the world. "Growth for 10 years at a rate similar to the rate of decline of the past 10 years is indicated". it says. The OSTP panel places a special emphasis on the potential contribution of university scientists in single-mindedly pursuing long-term goals rather than performing highly-specified research. The universities are a "logical" place to expect original and startling new ideas, it says.

This emphasis on supporting university research is already reflected in the department's budget. Between 1976 and 1978, for example, while Defense Department support for in-house basic research was kept constant (in current dollars). support for basic research in universities increased by almost $60 \%$. In 1976, universities carried out 33\% of the department's basic research; by 1978 the proportion had increased to $40 \%$.

There have also been shifts in the areas of research receiving support. From the US Air Force, for example, there has been a decline in support for nuclear physics or atmospheric research, and an increase in materials science and engineering. Mathematics. however, and particularly the computer sciences continue to receive good support.

So far there has been little opposition from the academic community to the re-emerging importance of Defense Department research funds. A few reecho the concerns of the late 1960s. "The trend is part of an overall growth of military spending and militarism in this country that I consider very unhealthy for science in its broader context-it's like saying that wars are good for surgery", says Dr Charles Schwarz. professor of physics at the University of California in Berkeley.

And a group of scientists in Boston have recently recommended that basic research be removed from the Department of Defense budget, where they say it has a "high probability of military applicability". They have suggested that the majority of the funds be transferred to a National Technology Foundation. which would stimulate $R \& D$ in areas of technology where private industry is not yet willing to undertake the work.

But most scientists are taking a more pragmatic line. They point out that. unlike the more applied research sponsored by the Defense Department in university-associated laboratories-such as MIT's Lincoln Laboratory-the basic research it supports is unclassified. And it also has spin-offs in other areas. 